\title{
MODEL VIDLJIVOSTI KAO STRATEGIJA ZA PREVENCIJU ŠUMSKIH POŽARA - PRIMJER ZADARSKE ŽUPANIJE*
}

\author{
VIEWSHED MODEL AS A STRATEGY FOR PREVENTION \\ OF FOREST FIRES - CASE STUDY OF ZADAR COUNTY
}

Ante ŠILJEG**, Ivan MARIĆ, Mladen JURIŠIĆ, Ivan PLAŠČAK

\begin{abstract}
SAŽETAK
Odabir motrilačkih lokacija protupožarnog sustava najčešće uključuje izvođenje analiza vidljivosti. Primjena analitičkih mogućnosti GIS-a, informacijsko-komunikacijskih tehnologija (ICT) te prostorno-orijentiranih podataka pruža osnovu nastanka i djelovanja protupožarnih video sustava.

U radu je na temelju indikatora vidljivog zemljišnog pokrova i udjela vidljivog područja u odnosu na ukupnu kopnenu površinu županije, vrednovano šest predloženih lokacija za postavljanje nadzornih kamera unutar Zadarske županije. Vrednovanje je izvršeno analizom preklapanja binarnog modela vidljivosti, tipa zemljišnog pokrova i sloja naselja. Analiza pogodnosti lokacija odrađena je u sklopu projekta „HOLISTIC“IPA programa jadranske prekogranične suradnje 2007.-2013. Rezultati analize ukazuju na to da dvije od šest predloženih lokacija nisu pogodne za postavljanje nadzornih kamera.

Na primjeru dvije potencijalne lokacije nadzornih kamera analiziran je utjecaj pogreške DMR-a na model vidljivosti. Prvi put je na specifičnom primjeru u RH kvantificirana razlika između vjerojatnog algoritma i standardne binarne metode određivanja vidljivosti. Iz rezultata se može zaključiti da pouzdanost modela vidljivosti, odnosno razlika između testiranih algoritama, ovisi o geomorfometrijskim obilježjima terena na kojem se analiza odvija.
\end{abstract}

KLJUČNE RIJEČl: analiza vidljivosti, vjerojatna i binarna vidljivost, digitalni model reljefa.

\section{UVOD}

\section{INTRODUCTION}

Pojam vidljivosti se odnosi na dva osnovna značenja: „vidjeti ili biti viđen“ $i$,sposobnost lakog primjećivanja“ (Vollmer 2012). Standardne analize vidljivosti odnose se na predviđanje međusobne vidljivosti (intervisibility analysis) i na identificiranje ukupne površine vidljivosti (viewshed analysis) s odabrane lokacije (Kim i dr. 2004). Analize vid- ljivosti se izvode u svrhu utvrđivanja površine ili postotka vidljivog područja s promatračke lokacije. To je jedan od najizvođenijih skupova prostornih analiza u GIS okruženju, a koristi se $u$ širokom pojasu aktivnosti: od lociranja telekomunikacijskih tornjeva (De Floriani 2005), vjetroturbina (Möller 2006), nadzornih kamera (Murray i dr. 2007), vatrogasnih tornjeva za nadzor požara (Marin i dr. 2012, Pompa-Garcíai dr. 2012, Bao i dr. 2015, Sakellariou i dr.

* Uključeno vidljivo područje izvan Zadarske županije

** Corresponding autor

Doc. dr. sc. Ante Šiljeg, e-pošta: asiljeg@unizd.hr; Ivan Marić, mag. geogr., e-pošta: imaric1@unizd.hr, Sveučilište u Zadru, Odjel za geografiju, Trg kneza Višeslava 9, 23000 Zadar; , prof. dr. sc. Mladen Jurišić, e-pošta: mjurisic@pfos.hr; Doc. dr. sc. Ivan Plaččak, e-pošta: ivan.plascak@pfos.hr, Poljoprivredni fakultet u Osijeku, Sveučilište J. J. Strossmayer u Osijeku, Trg Sv. Trojstva 3, 31000 Osijek. 
2015), analiza arheoloških nalazišta (Jones 2006, Alblas 2012) do zaštite ugroženih vrsta (Maichak i Schuler, 2004.). Šumski požari spadaju u najteže prirodne katastrofe (Rosavec i dr. 2009, Bao i dr. 2015). Jedna od najistaknutijih preventivnih mjera sprječavanja požara je instalacija protupožarnog motrilačkog sustava nadzora (Merino i dr. 2012, Bao i dr. 2015). U svrhu poboljšanja sposobnosti odgovora na takve prijetnje mnoge zemlje razvijaju učinkovite sustave prevencije nastanka i širenja požara (Lee i dr. 2002, Kovácsová i Antalová 2010).

Prema procjeni žestine i učestalosti požara otvorenog tipa Zadarska županija spada u najugroženije u RH (DUZS 2009, URL1, Mamut, 2011). S obzirom na to da u županiji ne postoji razvijen protupožarni motrilački sustav, na inicijativu „Upravnog odjela za razvoj i europske procese“, proveden je Strateški projekt „HOLISTIC“IPA program jadranske prekogranične suradnje 2007.-2013. Glavni cilj ovog rada predmet je provedenog projekta.

U sklopu istraživanja izvršena je analiza vidljivosti sa šest predloženih motrilačkih lokacija uzimajući u obzir tip vidljivog zemljišnog pokrova. Na temelju odgovarajućih indikatora vrednovane su predložene lokacije. U radu su prvi put na nekom prostoru u Hrvatskoj uspoređena dva konceptualno različita algoritma za izvođenje modela vidljivosti, binarni (binary) i vjerojatni (probable).

\section{MATERIJALI I METODE \\ 2. MATERIALS AND METHODS}

U procesu izrade rada, uz opće znanstveno-istraživačke metode, korištene su različite metode, tehnike i procedure. $\mathrm{U}$ istraživanju su primijenjene metode vektorizacije i interpolacije, metode odabira prostorne rezolucije te analize binarne i vjerojatne vidljivosti. Osim spomenutih, korištene su i statističke metode, metode usporedbe i metode kartografske vizualizacije za prikaz izlaznog rezultata istraživanja.

\subsection{Proces prikupljanja i obrade podataka 2.1 Data collection and processing}

Proces izrade modela vidljivosti temeljio se na analizi digitalnog modela reljefa (DMR), koji je za potrebe rada izrađen metodom poluautomatske vektorizacije izohipsi s topografskih karata u mjerilu 1:25000. DMR je pojednostavljeni prikaz reljefa u rasterskom obliku, specifične rezolucije, dobiven odabranom i znanstveno utemeljenom metodom interpolacije podataka o visinama, prikupljenih specifičnom izmjerom i obradom (Šiljeg 2013). Metodom interpolacije ANUDEM generiran je DMR veličine piksela 25 metara. Metoda ANUDEM je izrađena za stvaranje hidrološki ispravnog i što je moguće više optimalnog digitalnog modela (Hutchinson 1989). Veličina prostorne

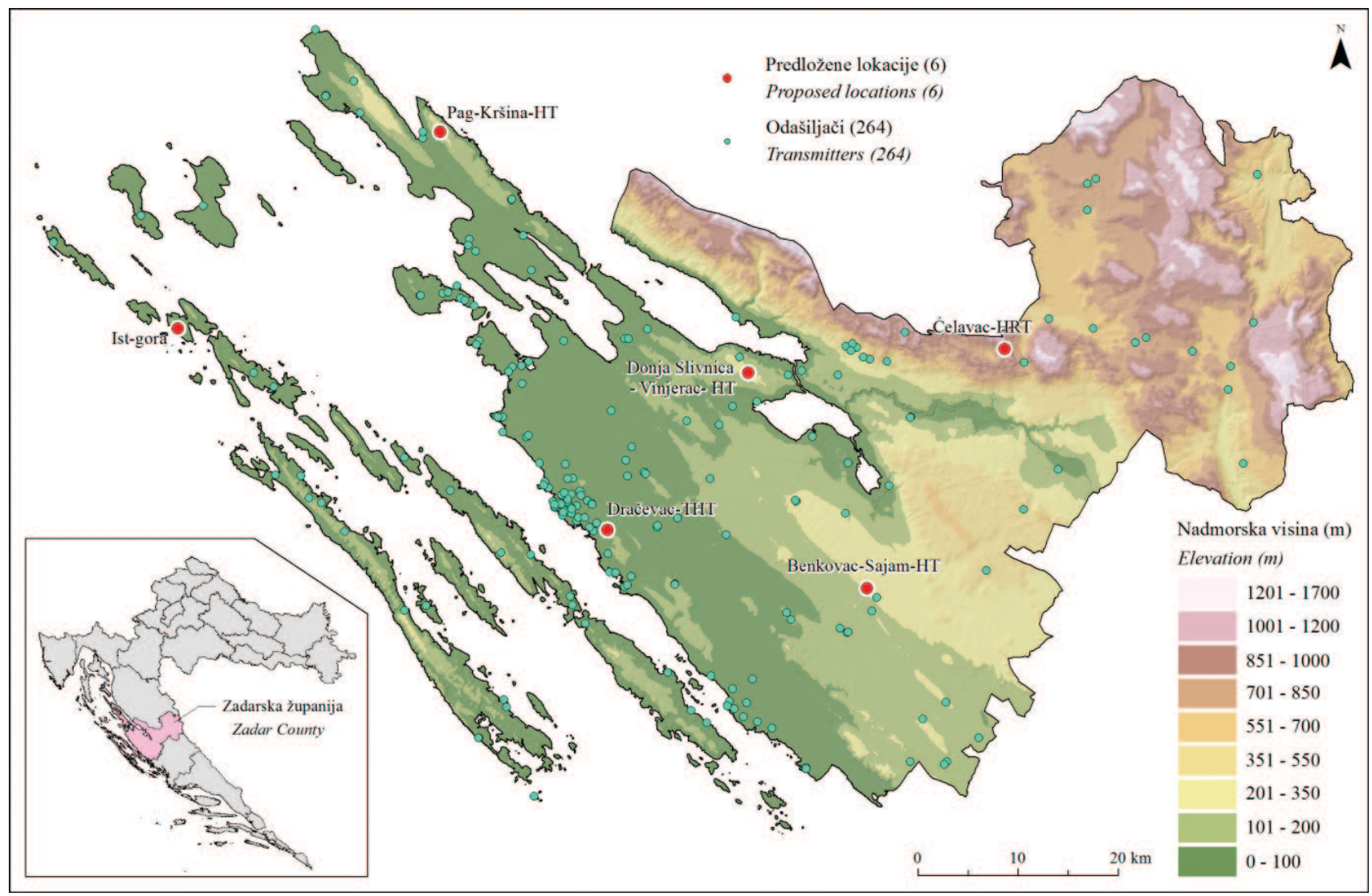

Slika 1. Geografski položaj istraživanog prostora i lokacije odašiljača

Figure 1 Geographic position of the research area and location of transmitters 
rezolucije određena je na temelju metode kompleksnosti terena. Za tu metodu karakteristično je da se veličina piksela računa na temelju dužine infleksijskih linija i broja točaka u njima (Hengl 2006).

Za potrebe određivanja tipa zemljišnog pokrova koji se nalazi unutar vidljivog područja korišten je podatak CORINE Land Cover. Temeljen je na standardnoj klasifikaciji i metodologiji izrade što pojednostavljuje usporedbu rezultata između europskih zemalja. Model pokrova generiran je postupkom reklasifikacije u sedam klasa slijedeći službenu kategorizaciju. Treća klasa naziva Šume i polu prirodna područja detaljnije je podijeljena na tri potklase (šume, grmlja i biljni pokrov te područja bez vegetacije) kako bi se preciznije mogli vrednovati indikatori pogodnosti potencijalnih lokacija.

Nositelji projekta dostavili su podatke o telekomunikacijskim odašiljačima koji reprezentiraju potencijale lokacije za postavljanje nadzornih kamera. Upravni odjel za razvoj i europske procese te vatrogasni službenici predložili su šest od dostavljenih 264 odašiljača (slika 1). Za predložene odašiljače bilo je potrebno provesti analizu vidljivosti.

\section{ANALIZA VIDLJIVOSTI UNUTAR GIS-A 3. GIS VIEWSHED ANALYSIS}

Osnovni podatci potrebni za izvođenje analiza vidljivosti unutar GIS-a su DMR i potencijalna lokacija nadzornog tornja. Izvođenje vidljivosti može biti izrazito vremenski zahtjevno, osobito ako DMR ima veliku prostornu rezoluciju (Lee 1994, Kim i dr. 2004). Analize vidljivosti najčešće se generiraju korištenjem modela "golog terena" (bare earth), odnosno DMR-a generiranog iz podataka koji su u većini slučajeva prikupljeni aerofotogrametrijom (Miller 2011). Ako se analizira prostor s izrazitim rizikom od požara, poželjno je da $80 \%$ njegove površine bude vidljivo $s$ postavljenog sustava nadzora. Taj postotak se naziva učinkovitost vidljivosti (visibility effectiveness). Manji postotci ne moraju biti nedovoljni, uzimajući u obzir veličinu promatranog prostora i dominantan tip vegetacije (PompaGarcía i dr. 2010, Sakellariou i dr. 2015).

Uključenje dvije ili više promatračkih točaka u analizu vidljivosti omogućuje izvođenje modela vizualne ranjivosti ( $v i$ sual vulnerability). Model vizualne ranjivosti ukazuje na to koliko je puta element rastera vidljiv sa svake promatračke točke (URL2).

\subsection{Parametri koji utječu na model vidljivosti 3.1 Impact parameters on the viewshed model}

Proces izvođenja analiza vidljivosti sastoji se od nekoliko faza. Prilikom izvođenja svakog koraka tog procesa javlja se opasnost od generiranja greške koja može utjecati na izlazni rezultat. Ta greška je posljedica korištenja određene tehnologije i nemogućnosti potpuno točnog reprezentira- nja zemljine površine. Dakle, čimbenici koji utječu na izlazni model vidljivosti mogu se podijeliti u nekoliko skupina: a) pogreška (error) DMR-a (Fisher 1999, Wechlser 1999), b) odabir prostorne rezolucije (Miller 2011), c) odabir algoritma (Fisher 1994, 1996, Wheatley i Gillings 2000, Rášová 2014), d) odabir parametara unutar GIS okruženja (URL 3), e) vanjski čimbenici (vegetacija, klima, infrastruktura) (Eliş 2013) if) parametri osjetljivosti detekcije požara u kameri (Bugarić i dr. 2014).

\subsection{Tipovi algoritama \\ 3.2 Types of algorithms}

\subsubsection{Binarna vidljivost}

\subsubsection{Binary viewshed}

Većina algoritama koji služe za izvođenje analiza temelje se na procesu binarne vidljivosti (binary viewshed). To je konceptualno privlačan i najčešće korišten način izvođenja vidljivosti koji se temelji na jednostavnom "polariziranom“ pravilu (vidljivo ili zaklonjeno) (Fisher 1996). Navedeni algoritam se temelji na Booleovu proizvodu (Boolean pro$d u c t$ ). Vrijednost lokacija (promatračke i promatrane) mora biti jednaka (1) kako bi izlazni rezultat označavao vidljivost. Bilo koji drugi oblik ulaznih podataka proizvodi lažno rješenje (Fisher 1992). Njegov princip rada temelji se na upotrebi DMR-a i promatračke točke koja ima postavljenu visinu u odnosu na izvornu visinu modela. Algoritam potom utvrđuje prelazi li teren preko linije pogleda (line-of-sight), odnosno zaklanja li u potpunosti pogled između promatračke i promatrane točke (Franklin i Ray 1994). Ako DMR ne prekida liniju pogleda, promatranom elementu rastera dodjeljuje se vrijednost 1 , što znači da je on vidljiv s te lokacije. Suprotno mu se dodjeljuje vrijednost 0 , što znači da se ne nalazi u vidljivom području (Fisher 1992). Dakle, dvije točke se definiraju kao vidljive jedna drugoj, ako ravna linija može biti provučena između njih bez presijecanja bilo kojeg dijela površine terena (Maloy i Dean 2001).

\subsubsection{Vjerojatna vidljivost}

\subsubsection{Probable viewshed}

Izuzev binarnog postoje i konceptualno kompleksniji algoritmi. Iako se binarni naširoko koristi, neki autori (Felleman 1990, Fisher 1992, Rášová 2014) navode njegove nedostatke. Naime, vidljivost nije isključivo polarna pojava. Prema njima svaka lokacija unutar istraživanog područja ima određenu vjerojatnost da bude vidljiva. Stoga ističu da je za generiranje vjernijeg prikaza vidljive površine potrebno uključiti više parametara (Fisher 1992, Wechsler 1999, Nagy 1994, Rášová 2014). Ključni parametar koji navode je pogreška DMR-a. Naime, DMR se često koristi kao osnova za izvođenje prostornih analiza bez kvantificirane pogreške koja je karakteristična za taj model. Drugim riječima DMR se često ne shvaća kao model terena već kao „točan“ prikaz zemljine površine (Wechsler 1999). Taj parametar se često 
Tablica 1. Udio vidljive površine unutar definiranog radijusa za predložene lokacije Table 1 Proportion of visible surface within defined radius for proposed sites

\begin{tabular}{|c|c|c|c|c|c|c|c|}
\hline \multirow{2}{*}{$\begin{array}{l}\text { Dračevac-THT } \\
\text { OFFSETA (m) }\end{array}$} & \multicolumn{3}{|c|}{$\begin{array}{l}\text { Radijus2 (km) } \\
\text { Radius2 (km) }\end{array}$} & \multirow{2}{*}{$\begin{array}{c}\text { Pag-Kršina-HT'1 } \\
\text { OFFSETA }\end{array}$} & \multicolumn{3}{|c|}{$\begin{array}{l}\text { Radijus2 (km) } \\
\text { Radius2 (km) }\end{array}$} \\
\hline & 5 & 10 & 15 & & 5 & 10 & 15 \\
\hline 10 & 73,0 & 58,2 & 45,9 & 10 & 48,8 & 54,8 & 52,9 \\
\hline 15 & 77,5 & 62,0 & 47,8 & 15 & 54,0 & 58,2 & 54,9 \\
\hline 20 & 81,0 & 64,4 & 53,5 & 20 & 57,2 & 61,2 & 56,4 \\
\hline Ćelavac-HRT ${ }^{*}$ & \multicolumn{3}{|c|}{$\begin{array}{l}\text { Radijus2 (km) } \\
\text { Radius2 (km) }\end{array}$} & Benkovac-Sajam-HT & \multicolumn{3}{|c|}{$\begin{array}{l}\text { Radijus2 (km) } \\
\text { Radius2 (km) }\end{array}$} \\
\hline OFFSETA (m) & 5 & 10 & 15 & OFFSETA & 5 & 10 & 15 \\
\hline 10 & 34,6 & 28,6 & 34,6 & 10 & 66,2 & 39,1 & 27,0 \\
\hline 15 & 35,7 & 29,8 & 35,4 & 15 & 69,5 & 41,9 & 28,7 \\
\hline 20 & 36,8 & 31,1 & 36,2 & 20 & 71,8 & 44,0 & 31,6 \\
\hline Ist-gora & \multicolumn{3}{|c|}{$\begin{array}{l}\text { Radijus2 (km) } \\
\text { Radius2 (km) }\end{array}$} & Donja Slivnica-Vinjerac-HT* & \multicolumn{3}{|c|}{$\begin{array}{l}\text { Radijus2 (km) } \\
\text { Radius2 (km) }\end{array}$} \\
\hline OFFSETA (m) & 5 & 10 & 15 & OFFSETA & 5 & 10 & 15 \\
\hline 10 & 49,9 & 63,5 & 65,6 & 10 & 41,0 & 54,5 & 45,7 \\
\hline 15 & 57,3 & 68,4 & 72,5 & 15 & 50,8 & 58,5 & 48,7 \\
\hline 20 & 66,5 & 74,6 & 77,6 & 20 & 56,2 & 61,3 & 51,4 \\
\hline
\end{tabular}

naziva učinak nesigurnosti DMR-a (Rášová 2014). Najznačajniji izvor pogreške u generiranju izlaznog rezultata je greška u izvornom skupu visinskih točaka. Naime, svi skupovi visinskih podataka imaju određenu marginu greške koja je najčešće mjeri u statističkom parametru srednje kvadratne pogreške (RMSE) (Ruiz 1997). Osim točnosti inicijalnog skupa podataka parametri koji mogu u model uvesti dodatnu pogrešku su: odabir neprimjerene metode interpolacije i prostorne rezolucije (Miller 2011). Smith i dr. (2003) navode da nasilno povećanje prostorne rezolucije, kroz zanemarivanje površine istraživanog prostora i broja uzorkovanih točaka, može povećati razinu pogreške u izrađenom modelu (Miller 2011). Zbog navedenih nedostataka određeni autori koriste algoritam vjerojatne (probable) vidljivosti (Rášová 2014).

Pogreška DMR-a može biti uključena u analize vidljivosti kroz Monte Carlo simulaciju gdje se vrijednosti modela nasumično mijenjaju uzimajući u obzir njegovu pogrešku. Monte Carlo simulacija se temelji na načelu da je DMR samo jedan od beskonačnog broja mogućih prikaza terena u rasponu pogreške modela (Nackaerts i dr. 1999). Oslanja se na broj ponavljanja slučajnog uzorkovanja u svrhu dobivanja vjernijih brojčanih rezultata. Ta metoda koristi se za rješavanja bilo kojeg problema vjerojatnosne orijentacije. Algoritam izračunava vidljivost na temelju visinskih vrijednosti modela koje uključuju pogrešku u margini unutar RMSE-a izvornog skupa visinskih podataka. Nakon što se odabere broj realizacija ( $n$ ) za svaki element rastera se izračunava binarna vidljivost na principu Booleova proizvoda (0 i 1). Rezultati tog algoritma za specifičan element rastera se zbrajaju preko niza iteracija. Što je više puta u iteracijama za određeni piksel izračunata vrijednost 1 , veća je vjerojatnost da će on biti vidljiviji (Fisher 1992, Worboys 1994, Fisher 1999, Alblas 2012).

Primjerice, ako algoritam izračunava vidljivost nekog piksela 20 puta i svaki put procijeni da je vidljiv, tad mu se pridodaje atribut $1(100 \%)$ što znači da se on uvijek nalazi unutar vidljivog područja. Međutim, ako od 20 ponavljanja piksel bude vidljiv samo 10 puta, tad mu se pridodaje atribut 0,5 (50\%) što znači da je vidljiv u pola situacija. Formula algoritma vjerojatne vidljivosti je:

$$
p\left(X_{i j}\right)=\frac{\sum_{k=1}^{n} x_{i j k}}{n}(\text { Fisher 1999) }
$$

gdje je:

$\mathrm{p}\left(\mathrm{X}_{\mathrm{ij}}\right)=$ vjerojatnost da će piksel u biti vidljiv s točke promatranja

$\mathrm{x}_{\mathrm{ijk}} \quad=$ vrijednost binarno kodirane vidljivosti $\mathrm{u}$ pikselu koja poprima vrijednost 1

$\mathrm{n} \quad=$ broj ponavljanja

\section{REZULTATI I RASPRAVA}

\section{RESULTS AND DISCUSSION}

Modeli vidljivosti za šest predloženih lokacija nadzornih kamera generirani su koristeći binarni algoritam. Navedeni algoritam je korišten zato što je konceptualno jednostavniji i njegovo izvođenje zahtjeva manju upotrebu radne memorije. Na temelju dostavljene projektne dokumentacije po- 


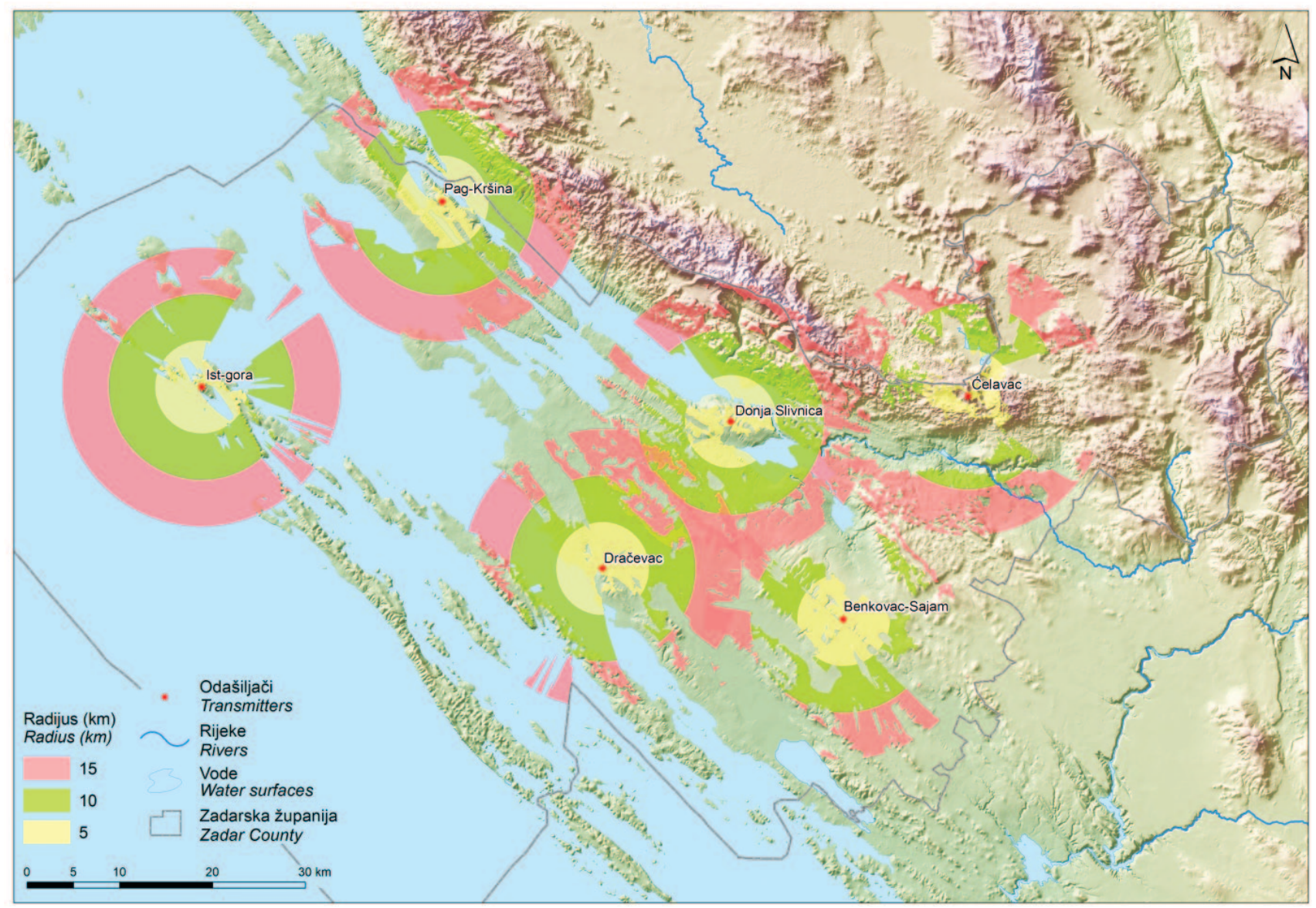

Slika 2. Modeli vidljivosti za šest predloženih lokacija ( $r=5,10$ i $15 \mathrm{~km})$ Figure 2 Viewshed models for the six proposed sites ( $r=5,10$ and $15 \mathrm{~km})$

stavljeni su parametri vidljivosti unutar GIS-a: azimut $360^{\circ}$, vertikalni kut od $-90^{\circ}$ do $90^{\circ}$ te OFFSETB $5 \mathrm{~m}$. Prema zadanim parametrima za svaku predloženu lokaciju generirano je nekoliko modela vidljivosti (slika 2). Postavljena je visina kamere od 10, 15 i $20 \mathrm{~m}$. Udio vidljivosti za svaku potencijalnu lokaciju izračunat je u radijusu od 5,10 i $15 \mathrm{~km}$.

Za predložene lokacije definiran je udio vidljive površine unutar ukupne površine postavljenog radijusa (tablica 1). Gotovo na svim lokacijama najveći postotak vidljivosti je zabilježen unutar radijusa od $5 \mathrm{~km}$, s postavljenom visinom kamere od $20 \mathrm{~m}$ iznad zemlje. Najmanji udijeli vidljivog prostora, izuzev lokacije Ist-gora, prevladavaju u najvećem radijusu s najnižom visinom postavljene kamere $(10 \mathrm{~m})$.

Najveći postotak vidljivosti za lokaciju Pag zabilježen je unutar radijusa od $10 \mathrm{~km}$, s maksimalnom visinom kamere. Povećanjem radijusa na $15 \mathrm{~km}$ unutrašnjost Velebita ostaje zaklonjena uslijed prekidanja linije pogleda (slika 2). Najveći postotak vidljivosti za lokaciju Donja Slivnica zabilježen je unutar radijusa od $10 \mathrm{~km} \mathrm{~s}$ maksimalnom visinom kamere. Udjeli vidljive površine za najmanji i najveći radijus ne razlikuju se mnogo po postotku. Naime, povećanjem radijusa, zbog povoljne morfologije okolnog terena, postaje vidljiv JZ, J i JI zaravnjen prostor te južni obronci Velebita.
Ova lokacija može biti povoljna za smještaj nadzorne kamere, što je najbolje vidljivo na perspektivnom prikazu vidljivog područja (slika 3).

Najveći dio zaklonjenog prostora za odašiljač Dračevac nalazi se JI od predložene lokacije. To je zbog uzvišenja (Brdo Križ), koje prekida liniju pogleda, pružajući se u smjeru SZJI iznad Bibinja (slika 2). Za vrijeme Domovinskog rata to je bila jedna od najistaknutijih strateških točki užeg zadarskog područja. Lokacija Ćelavac najveći postotak vidljivosti bilježi unutar radijusa od $5 \mathrm{~km}, \mathrm{~s}$ maksimalnom visinom kamere. Najmanji udio vidljivosti je u radijusu od $10 \mathrm{~km} \mathrm{~s}$ najmanjom visinom kamere. Naime, povećanjem radijusa na $15 \mathrm{~km}$ vidljiv postaje velik dio prostora J od predložene lokacije. Taj prostor je zaravnjen što omogućuje povlačenje linije pogleda (slika 2). Najveći postotak vidljivosti lokacije Benkovac zabilježen je unutar radijusa od $5 \mathrm{~km}$, s najvećom visinom kamere. Naime, povećanjem radijusa velik prostor ostaje zaklonjen uslijed reljefnih zapreka koje se nalaze SI i JZ od potencijalne lokacije (slika 2). Potrebno je istaknuti glavni nedostatak lokacije Ist-gora. Iako bilježi velike vrijednosti vidljive površine one nisu relevantne za proučavanu problematiku. Naime, veliki udio vidljivog prostora odnosi se na more. Prava vrijednost ove lokacije procijenit 


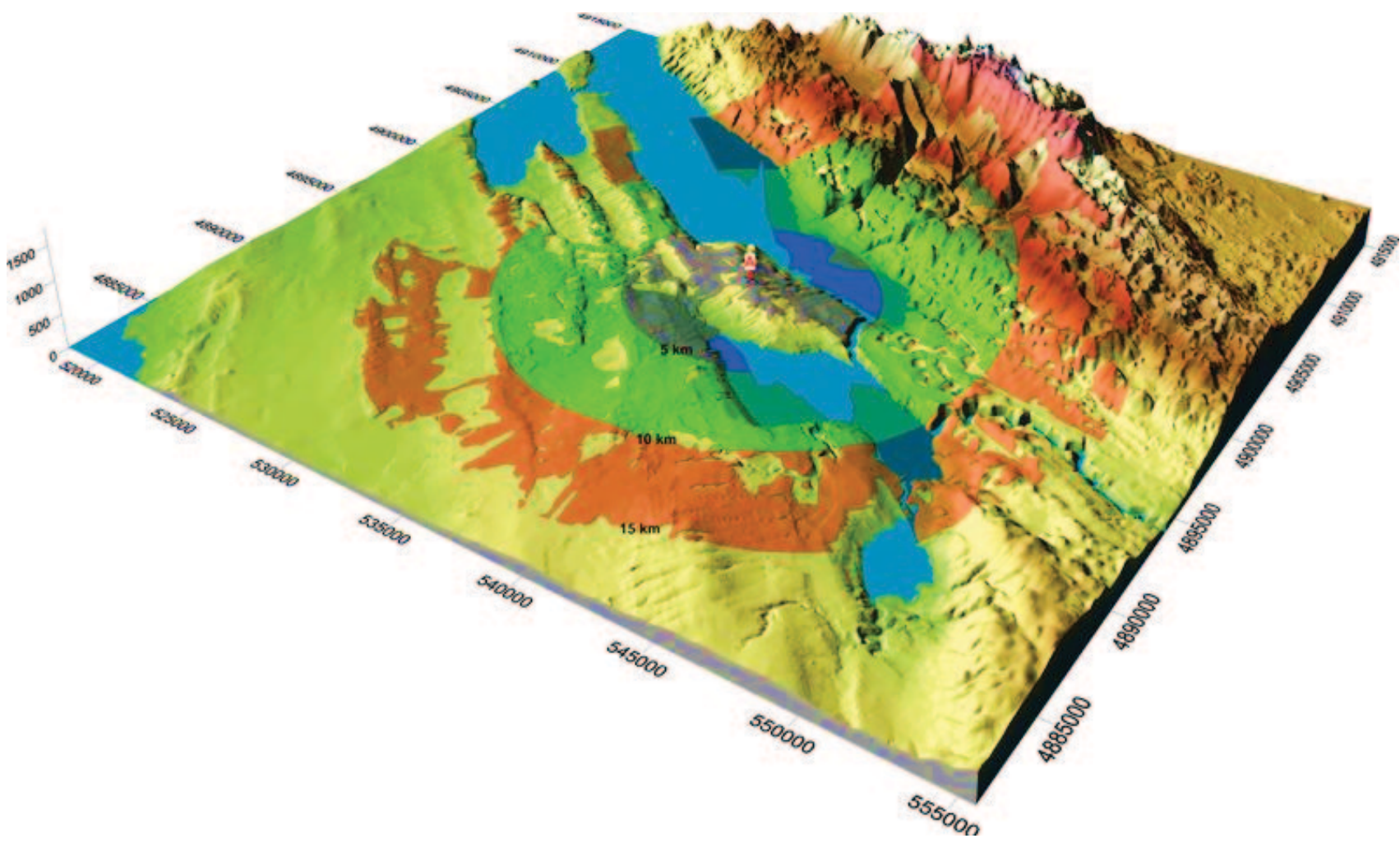

Slika 3. Perspektivni prikaz vidljivog područja za lokaciju Donja Slivnica - primjer dobre lokacije Figure 3 A perspective view of the visible area for the site Donja Slivnica - example of good location

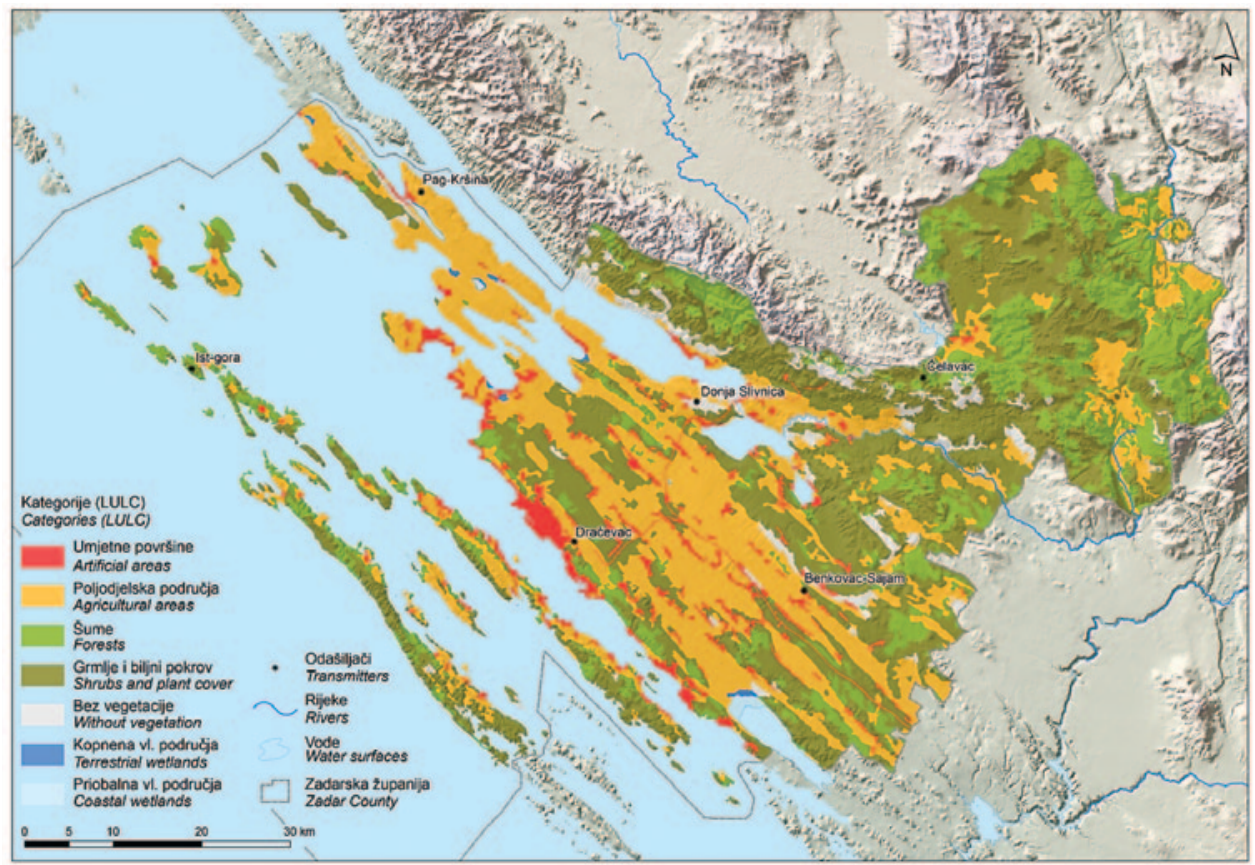

Slika 4. Model zemljišnog pokrova Zadarske županije

Figure 4 Land cover model of Zadar County

će se tek nakon određivanja kategorija zemljišnog pokrova koji prevladavaju u vidljivom području (slika 2).

U binarnom algoritmu model vidljivosti ovisi isključivo o morfologiji okolnog terena koja može prekidati liniju pogleda. Za potrebe vizualnog isticanja navedenog učinka prikazan je primjer potencijalno dobrog (slika 3) odabira lo- kacije gdje je vidljivo kako morfologija terena prekida liniju pogleda i sprječava generiranja većeg vidljivog područja. Prilikom izvođenja seta indikatora koji kvantificiraju pogodnost predloženih šest lokacija korišteni su modeli radijusa $15 \mathrm{~km}$ s kamerom na visini od $20 \mathrm{~m}$, zato jer su ti parametri propisani u projektnoj dokumentaciji. Udio 


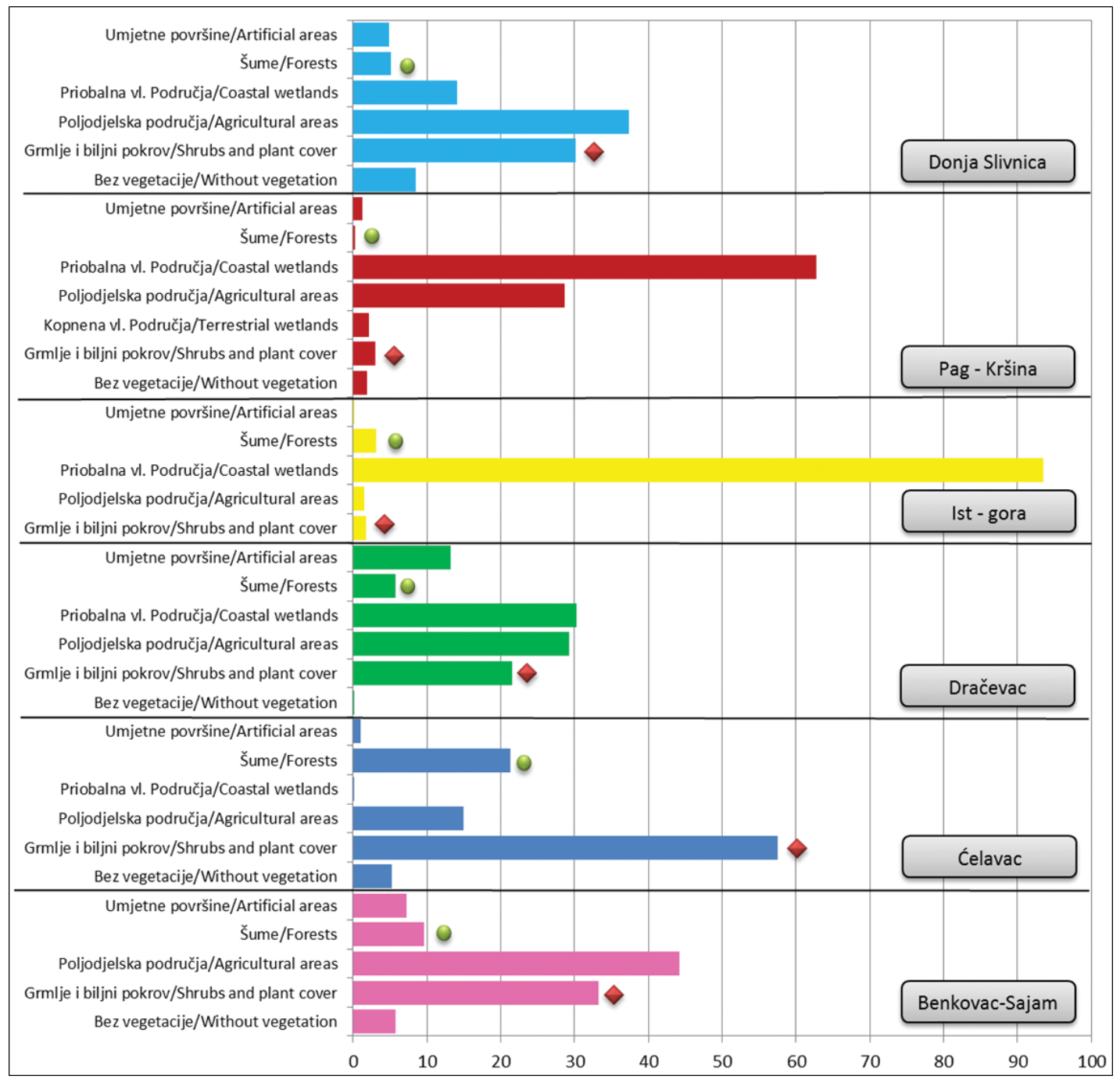

Slika 5. Udio klasa zemljišnog pokrova unutar vidljivog područja do $15 \mathrm{~km}$ Figure 5 Proportion of land cover classes within the visible area up to $15 \mathrm{~km}$

vidljivog područja unutar zadanog radijusa nije najbolji pokazatelj na temelju kojeg bi se trebalo vrednovati predložene lokacije. Najbolji primjer za to je Ist-gora gdje je generiran velik udio vidljivog područja koji reprezentira isključivo more i uski obalni prostor.

\subsection{Odnos vidljivog područja i zemljišnog pokrova 4.1 The relation of the visible area and land cover}

Važan čimbenik kod odabira lokacija je tip zemljišnog pokrova koji se nalazi unutar vidljivog prostora (Pompa-Garcíai dr. 2012, Sivrikaya i dr. 2014). Kategorije zemljišnog pokrova najrizičnije od zapaljenja su: šume, grmlje i biljni pokrov. Na njih se stavlja poseban naglasak prilikom nadzora (Jaiswal i dr. 2002). Na slici 4 vidljiva je distribucija klasa zemljišnog pokrova Zadarske županije.

Preklopljen je model zemljišnog pokrova s modelima vidljivosti svih šest predloženih lokacija nadzornih tornjeva. Najveće površine zemljišnog pokrova bez nadzora kamere nalaze u SI i I dijelu županije. Tu prevladavaju veće nad- morske visine, odnosno najrizičnije klase zemljišnog pokrova. Razlog tome je nedostatak lokacije odašiljača koji bi se nalazilo SI ili I od lokacije Ćelavac. Preklapanjem modela vidljivosti i kategorija zemljišnog pokrova izvedeno je osam indikatora za svaku klasu koja se nalazi unutar vidljivog prostora predloženih lokacija. Dobivene vrijednosti su poslužile u procesu vrednovanja. Poseban naglasak je stavljen na indikatore površine i udjela vidljivog područja šume, grmlja i biljnog pokrova u ukupnoj površini vidljivog prostora (slika 5).

Prema generiranim indikatorima lokacije Ćelavac, Donja Slivnica, Dračevac i Benkovac bilježe znatno bolje rezultate u odnosu na ostale dvije lokacije. S lokacije Ćelavac vidljiva je najveća površina šume, grmlja i biljnog pokrova (15123 ha), potom slijede Donja Slivnica (11776 ha) pa Dračevac (10282 ha). Vrijednosti za lokacije Ćelavac i Donja Slivnica bile bi još veće da je uračunat prostor izvan Zadarske županije. Najveći udio spomenutih kategorija u ukupnom vidljivom području ima lokacija Ćelavac, potom sa sličnim 


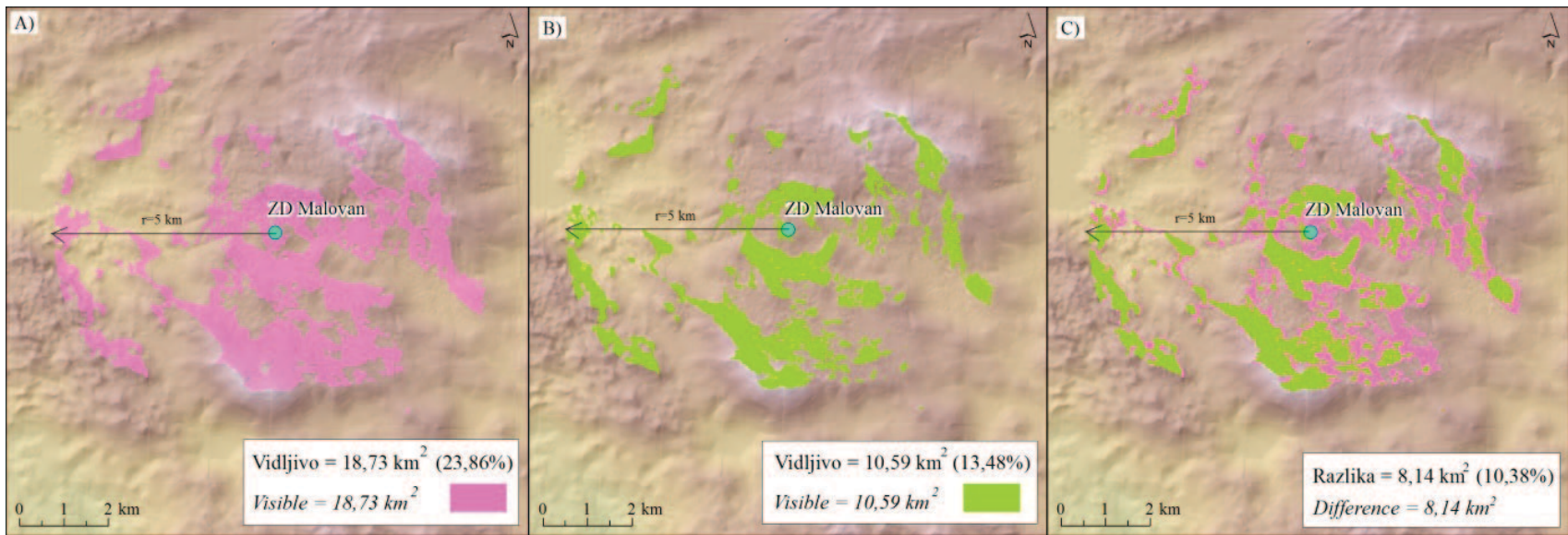

Slika 6. A) Površina i udio vidljivog područja prema binarnom algoritmu - ZD Malovan B) Površina i udio $100 \%$ vidljivog područja prema vjerojatnom algoritmu - ZD Malovan C) Razlika u površini i udjelu binarnog i vjerojatnog algoritma - ZD Malovan

Figure 6 A) Area and proportion of the visible area according to binary algorithm - ZD Malovan B) Area and proportion of the 100\% visible area according to probable algorithm - ZD Malovan C) The difference in area and proportion of binary and the probable algorithm - ZD Malovan.

vrijednostima slijede lokacije Benkovac i Donja Slivnica. Potrebno je istaknuti lokacije Ist i Pag kao primjere lošeg odabira za postavljanje nadzorne kamere. Više od $93 \%$ i $60 \%$ vidljivog područja spomenutih lokacija spada u kategoriju priobalnih vlažnih područja (more) (slika 5). Iako nije predložena, lokacija Ugljan-Sveti Mihovil-HRT bila bi puno bolji odabir od prethodnih lokacija. Naime, s lokacije Ist se nadzire 3545,7 ha kopnene površine, s Paga 9681,9 ha, dok bi se s odašiljača na koti Sv. Mihovil moglo nadzirati čak 15742,5 ha.

\subsection{Odnos naselja i vidljivog područja}

\subsection{The relation of settlements and the visible area}

Preklapanjem modela vidljivosti i naselja unutar Zadarske županije utvrđena je pokrivenost naselja nadzornim sustavom. Od 230 naselja unutar Zadarske županije, njih 70\%
(161) ima jedan dio površine definiran kao vidljivo područje s jednog od šest predloženih nadzornih tornjeva. Ostalih 30\% (69) nema dio površine definiran kao vidljivo područje. Najveći dio tih naselja nalazi se na prostoru istočnog dijela Zadarske županije. Razlog tome je nedostatak nadzornih tornjeva u blizini. Manji broj naselja bez dijelova vidljivog područja nalaze se na području zadarskog arhipelaga. Razlog je samo jedna predložena lokacija nadzorne kamere i to na otoku Istu.

Na temelju analize izvedena su četiri indikatora koja pobliže označuju koje su lokacije najprimjerenije za postavljanje nadzornih kamera. Prema generiranim indikatorima kao najbolje lokacije ističu se: Dračevac, Donja Slivnica, Benkovac i Ćelavac. One bilježe najveću površinu i opseg vidljivog kopnenog područja. Vidljivo kopneno područje s te četiri lokacije zajedno čini $87,87 \%\left(965,76 \mathrm{~km}^{2}\right)$ ukupne

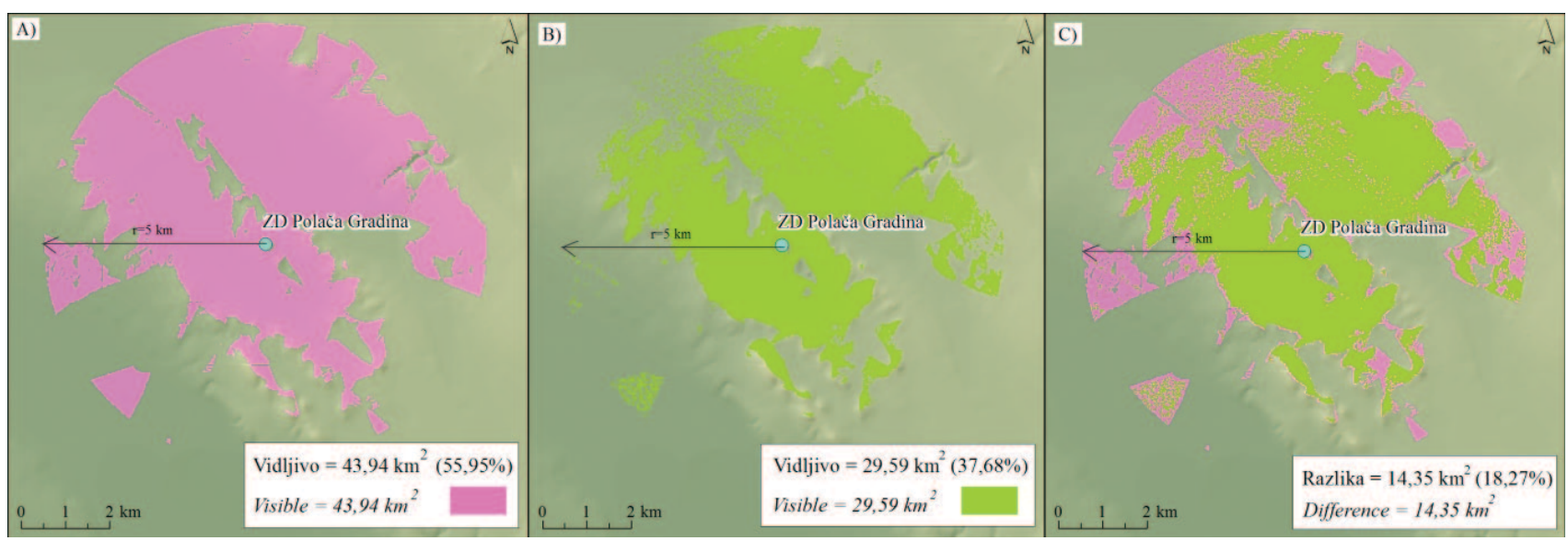

Slika 7. A) Površina i udio vidljivog područja prema binarnom algoritmu - ZD Polača Gradina B) Površina i udio 100\% vidljivog područja prema vjerojatnom algoritmu - ZD Polača Gradina C) Razlika u površini i udjelu binarnog i vjerojatnog algoritma - ZD Polača Gradina

Figure 7. A) Area and proportion of the visible area according to binary algorithm - ZD Polača Gradina B) Area and proportion of the 100\% visible area according to probable algorithm - ZD Polača Gradina C) The difference in area and proportion of binary and the probable algorithm - ZD Polača Gradina. 
površine vidljivog kopnenog područja svih šest nadzornih tornjeva u radijusu od $15 \mathrm{~km}$.

Ustanovljeno je da udjel vidljivog kopnenog područja u odnosu na ukupnu kopnenu površinu županije u prosjeku iznosi 5,02\%. Raspon vrijednosti iznosi 6,86\%. Predložene lokacije Benkovac, Ćelavac, Dračevac i Donja Slivnica bilježe veću vrijednost od srednjaka. S navedenih lokacija ukupno je vidljivo 26,47\% kopnene površine županije. S ostale dvije lokacije (Ist i Pag) vidljivo je tek 3,66\% kopnene površine. Ukupan udio vidljivog kopnenog područja s predloženih šest lokacija nadzornih tornjeva iznosi 30,13\% ukupne površine županije. Lokacija Ist (0,99\%) bilježi 2,5 puta manju vrijednost udjela vidljivog područja u ukupnoj površini županije od lokacije Pag (2,67\%) koja je druga najlošija prema ovom pokazatelju. Kada bi se nadzorna kamera postavila na lokaciji Ugljan-Sveti Mihovil-HRT bilo bi moguće nadzirati 4,32\% ukupne kopnene površine županije, što je gotovo dva puta više od lokacije Pag.

\subsection{Usporedba vjerojatnog i binarnog algoritma 4.3 Comparison of the probable and binary algorithm}

Generiran je model vjerojatne i binarne vidljivost za nove lokacije odašiljača te je kvantificirana njihova razlika u vidljivom području. Vidljivo područje u binarnom algoritmu ima vrijednost 1 , dok se u vjerojatnom označava kao raspon vrijednosti od 0-1. Kako bi izlazni rezultati bili usporedivi, iz modela vjerojatne vidljivosti izdvojeni su oni pikseli koji imaju stopostotnu vjerojatnost (1 ili 100\%) da će biti uočeni $\mathrm{s}$ promatračke točke.

Parametar ponavljanja (n) u Monte Carlo simulaciji postavljen je na 100 slijedeći pristup Nackaerts i dr. (1999) i Rášová (2014). Zbog vremenske zahtjevnosti izvođenja analize i velike upotrebe radne memorije, razlika između algoritama utvrđena je na primjeru dva odašiljača čiji okolni prostor obilježavaju različita geomorfometrijska svojstva. Prvi odašiljač naziva se ZD Malovan, nalazi se na 896 m nadmorske visine. Okolni prostor ovog odašiljača obilježava velika nadmorska visina, veliki nagibi te izražena energija reljefa. Drugi odašiljač je ZD Polača Gradina na visini od $145 \mathrm{~m}$. Njegov okolni prostor obilježavaju suprotne geomorfometrijske karakteristike. Koristeći niski srednji filter (low mean filter) u obzir je uzeta prostorna autokorelacija pogreške DMR-a (Rášová 2014). On zaglađuje podatke smanjenjem lokalne varijacije i uklanjanjem buke. U pokretnoj mreži kvadrata (3x3) izračunava se srednjak za središnji piksel tako uklanjajući nepravilnosti, odnosno ekstremne vrijednosti unutar DMR-a (URL 5).

Analize vidljivosti su izvedene na temelju DMR-a koji je kao ulazni podatak (izohipse) imao visinske atribute preuzete iz topografskih karata mjerila 1:25000. S obzirom na to da se izvodi model vjerojatne vidljivosti, potrebno je „uračunati“ grešku ulaznih podataka. Glavni ulazni visinski podatak bile su izohipse. Puceković (2014) analizira stvarnu ocjenu visinske točnosti TK25. Kao „istinite“, odnosno referentne vrijednosti služile su visine na kartama 1:5000 (Puceković 2014). Drugim riječima te točke predstavljaju eksterni set kontrolnih točaka (external set of control points) na temelju kojih se određuje pogreška. Navodi da iz Kopeovih jednadžbi visinska pogreška izohipsi iznosi od 0,5 (ravnice) do $6 \mathrm{~m}$ (veći nagibi) (Puceković 2014). Unutar algoritma vjerojatne vidljivosti korištena je UNIFORM distribucija pogreške modela, $s$ definiranim vrijednostima minimalne $(0,5 \mathrm{~m})$ i maksimalne $(6 \mathrm{~m})$ pogreške. Prostorna rezolucija izlaznog rezultata postavljena je prema onoj DMR-a $(25 \mathrm{~m})$. Točkama promatranja s postojećom visinom pridodan je parametar OFFSETA u vrijednosti $20 \mathrm{~m}$, a vidljivost je izračunata $\mathrm{u}$ radijusu od $5 \mathrm{~km}$ zbog vremenske zahtjevnosti procesa.

Iz dobivenih rezultata potvrđuju se navodi autora Fisher (1992) koji je prvi proučavao utjecaj „nesigurnost“ DMR-a $\mathrm{u}$ analizama vidljivosti. On navodi da izvorni algoritam „precjenjuje“ veličinu vidljivog područja (Fisher 1992, Nagy 1994). Drugim riječima algoritam binarne u odnosu na vjerojatnu vidljivosti generira veće površine vidljivog prostora. Naime, kad se simulacijom DMR povisi za vrijednost pogreške, dijelovi terena prekidaju liniju pogleda što rezultira smanjivanjem vidljivog područja. S druge strane slučaj smanjenja visine na temelju vrijednosti pogreške, ne uzrokuje otvaranje novih vidika, odnosno ne povećava znatnije vidljivu površinu (Fisher 1992). Vidljivo je da promatračka točka na većoj nadmorskoj visina generira manju razliku uspoređenih algoritama u izlaznom rezultatu (10,38\%) (slika 6 i 7). To znači da je utjecaj procijenjene pogreške veći na zaravnjenom terenu (18,27\%), gdje mala razlika u visini može zakloniti veću površinu nego što bi to bilo u vertikalno raščlanjenijem terenu (Nagy 1994, Huss i Pumar 1997). Drugim riječima prva točka (ZD Malovan) je manje „podložna“ pogrešci od točke na nižoj nadmorskoj visini $(18,27 \%)$ koju okružuje u potpunosti zaravnjen prostor. To znači da oba algoritma procjenjuju vidljivo područje u manjem rasponu pogreške za prvu promatračku točku.

\section{ZAKLJUČNA RAZMATRANJA}

\section{FINAL REMARKS}

Primjenom binarnog algoritma generirani su modeli vidljivosti za šest predloženih lokacija postavljanja kamera u svrhu organiziranja protupožarnog nadzornog video-sustava Zadarske županije. Provedene analize imaju ključnu ulogu prilikom odabira najboljih lokacija. Integriranjem DMR-a, modela vidljivosti i tipa zemljišnog pokrova izvedeni su indikatori koji su prepoznati kao relevantni prilikom odabira lokacije. Posebnu važnost imaju indikatori: površina vidljivih šuma, grmlja i biljnog pokrova te udio vidljivog područja u odnosu na ukupnu kopnenu površinu 
županije. Provedenim istraživanjem zaključeno je da od šest predloženih lokacija Ist-gora i Pag-Kršina-HT nisu primjerene za postavljanje nadzornih kamera. Naime, lokaciji Istgora gotovo $94 \%$ vidljive površine opada na more te pod nadzorom ima manje od 1\% kopnene površine županije. Lokacija Pag-Kršina-HT bilježi nešto veći udio kopnene površine pod nadzorom (2,67\%), manji udio vidljive površine joj opada na more (63\%), ali pod vidljivim dijelom kopnene površine ima samo 846 ha šuma, grmlja i biljnog pokrova, što je 3,17 puta manje od sljedeće najlošije lokacije (Ist-gora). Na temelju generirane statistike predlaže se Ugljen-Sv.Mihovil-HRT kao potencijalna lokacija za instalaciju nadzornih kamera u svrhu nadzora otoka zadarskog arhipelaga. Predložena lokacija bilježi znantno bolje vrijednosti od prethodne dvije (Ist i Pag).

Primjenom binarnog i vjerojatnog algoritma na primjeru dvije lokacije odašiljača potvrđeno je da pouzdanost mjerenja vidljivosti ovisi o točnosti DMR-a i vrsti terena na kojoj se ta analiza odvija. Ako se $u$ analizu integrira pogreška DMR-a, na vertikalno raščlanjenom, višem terenu, predviđanje, odnosno razlika između algoritama, ispada manja nego na zaravnjenim prostorima. Naime, što je teren „grublji“ pogreška ima manji utjecaj na vidljivost, jer su razlike između visina veće. Što je teren zaravnjeniji i najmanja dodana pogreška može prekinuti liniju pogleda i zakloniti veliko područje. Iz toga se može zaključiti da su sve analize vidljivosti lokacijski specifične. Daljnja istraživanja trebalo bi usmjeriti prema terenskoj provjeri generiranih modela vidljivost na način da se integriraju GPS tehnologija i terenska opažanja te kroz odgovarajući set uzoraka provjeri točnost modela.

\section{LITERATURA}

\section{REFERENCES}

- Alblas, L., 2012: Archaeological Visibility Analysis with GIS, The Council of European Geodetic Surveyors, Department of Archaeology, University of Glasgow, pp 7.

- Bao, S., Xiao, N., Lai, Z., Zhang, H., Kim, C., 2015: Optimizing watchtower locations for forest fire monitoring using location models, Fire Safety Journal, 71, 100-109.

- Bugarić, M., Jakovčević, T., Stipaničev, D., 2014: Adaptive estimation of visual smoke detection parameters based on spatial data and fire risk index, Computer vision and image understanding, 118, 184-196.

- Chuvieco, E., Salas, J., 1996: Mapping the spatial distribution of forest fire danger using GIS, International Journal of Geographical Information Science, 10(3), 333-345.

- De Floriani, L., Marzano, P., Puppo, E., 1994: Line-of-sight communication on terrain models, International Journal of Geographical Information Systems, 8(4), 329-342.

- Eliş, H., Tansel, B., Oĝuz, O., 2013: The viewshed problem: a theoretical analysis and a new algorithm for finding the viewshed of a given point on a triangulated terrain, Optimization Online, Bilkent University.
- Felleman, J., 1990: The role of error in GIS-based viewshed determination: A problem analysis, US Forest Service

- Fisher, P. F., 1992: First experiments in viewshed uncertainty: simulating fuzzy viewsheds, Photogrammetric engineering and remote sensing, 58, 345-345.

- Fisher, P. F., 1994: Probable and fuzzy models of the viewshed operation, Innovations in GIS, 1, 161-175.

- Fisher, P. F., 1996: Extending the applicability of viewsheds in landscape planning, Photogrammetric Engineering and Remote Sensing, 62(11), 1297-1302.

- Fisher, P. F., 1999: Models of uncertainty in spatial data, Geographical information systems, 1, 191-205.

- Franklin, W. R., Ray, C., 1994: Higher isn't necessarily better: Visibility algorithms and experiments, In Advances in GIS research: sixth international symposium on spatial data handling (Vol. 2, pp. 751-770), Taylor \& Francis Edinburgh.

- Hengl, T., 2006: Finding the right pixel size, Computers \& Geosciences, 32(9), 1283-1298.

- Hutchinson, M. F., 1989: A new procedure for gridding elevation and stream line data with automatic removal of spurious pits, Journal of Hydrology, 106(3-4), 211-232.

- Huss, R. E., Pumar, M. A., 1997: Effect of database errors on intervisibility estimation, Photogrammetric Engineering and Remote Sensing, 63(4), 415-424.

- Jaiswal, R. K., Mukherjee, S., Raju, K. D., Saxena, R., 2002: Forest fire risk zone mapping from satellite imagery and GIS, International Journal of Applied Earth Observation and Geoinformation, 4(1), 1-10.

- Kim, Y. H., Rana, S., Wise, S., 2004: Exploring multiple viewshed analysis using terrain features and optimisation techniques, Computers \& Geosciences, 30(9), 1019-1032.

- Kovácsová, P., Antalová, M. (2010): Precision forestry-definition and technologies, Šumarski list, 134(11-12), 603-610.

- Jones, E. E., 2006: Using viewshed analysis to explore settlement choice: A case study of the Onondaga Iroquois, American Antiquity, 523-538.

- Lee, J., 1994: Digital analysis of viewshed inclusion and topographic features on digital elevation models, Photogrammetric Engineering and Remote Sensing; United States, 60(4).

- Lee, B. S., Alexander, M. E., Hawkes, B. C., Lynham, T. J., Stocks, B. J., Englefield, P., 2002: Information systems in support of wildland fire management decision making in Canada, Computers and Electronics in Agriculture, 37(1), 185-198.

- Maichak, E. J., Schuler, K. L., 2004: Applicability of viewshed analysis to wildlife population estimation, The American midland naturalist, 152(2), 277-285

- Maloy, M. A., Dean, D. J., 2001: An accuracy assessment of various GIS-based viewshed delineation techniques, Photogrammetric Engineering and Remote Sensing, 67(11), 1293-1298.

- Mamut, M. (2011): Veza prirodnogeografske i sociogeografske osnove Dalmacije s ugroženošću otvorenog prostora požarom, Šumarski list, 135(1-2), 37-49.

- Marín, P. G., Maico, Z. M., Ciro, H. D., Efraín, R. T., 2012: Geospatial model as strategy to prevent forest fires: A case study, Journal of Environmental Protection, 2012.

- Merino, L., Caballero, F., Martínez-de-Dios, J. R., Maza, I., Ollero, A., 2012: An unmanned aircraft system for automatic forest fire monitoring and measurement, Journal of Intelligent \& Robotic Systems, 65(1-4), 533-548. 
- Miller, M. L., 2011: Analysis of Viewshed Accuracy with Variable Resolution LIDAR Digital Surface Models and Photogrammetrically-Derived Digital Elevation Models, Doctoral dissertation, Virginia Polytechnic Institute and State University.

- Möller, B., 2006: Changing wind-power landscapes: regional assessment of visual impact on land use and population in Northern Jutland, Denmark, Applied energy, 83(5), 477-494.

- Murray, A. T., Kim, K., Davis, J. W., Machiraju, R., Parent, R., 2007: Coverage optimization to support security monitoring, Computers, Environment and Urban Systems, 31(2), 133-147.

- Nackaerts, K., Govers, G., Loots, L., 1999: The use of MonteCarlo techniques for the estimation of visibility, BAR INTERNATIONAL SERIES, 750, 63-66.

- Nagy, G., 1994: Terrain visibility, Computers \& graphics, 18(6), 763-773.

- Pompa-García, M., Solís-Moreno, R., Rodríguez-Téllez, E., Pinedo-Álvarez, A., Avila-Flores, D., Hernández-Díaz, C., Velasco-Bautista, E., 2010: Viewshed analysis for improving the effectiveness of watchtowers, in the north of Mexico, Open Forest Science Journal, 3, 17-22.

- Puceković, B., 2014: Ispitivanje točnosti Topografske karte u mjerilu 1: 25000 u izdanju Vojnogeografskog instituta u Beogradu, Geodetski list, 68(1), 33-46.

- Rášová, A., 2014: Fuzzy viewshed, probable viewshed, and their use in the analysis of prehistoric monuments placement in Western Slovakia, Proceedings of the AGILE'2014 International Conference on Geographic Information Science, Castellón.

- Rosavec, R., Dominko, D., Barčić, D., Starešinić, D., Španjol, Ž., Biljaković, K., Bognolo, D. (2009): Analiza raspodjele površina zahvaćenih šumskim požarom na otocima Braču, Korčuli i Rabu, Šumarski list, 133(5-6), 301-307.

- Ruiz, M. O., 1997: A causal analysis of error in viewsheds from USGS digital elevation models, Transactions in GIS, 2(1), 8594.

- Sakellariou, S., Tampekis, S., Samara, F., Christopoulou, O., Sfougaris, A., 2015: Observatories Establishment for the Prevention of Forest Fires - The case of Thasos Island, Greece, In- ternational Journal of Innovative Technology and Exploring Engineering, 5(7).

- Sivrikaya, F., Sağlam, B., Akay, A. E., Bozali, N., 2014: Evaluation of forest fire risk with GIS, Polish Journal of Environmental Studies, 23(1), 187-194.

- Smith, S. L., Holland, D. A., Longley, P. A., 2003: The effect of changing grid size in the creation of laser scanner digital surface models, In 7th Int. Conf. GeoComputation, Southampton, UK.

- Šiljeg, A., 2013: Digitalni model reljefa u analizi geomorfometrijskih parametara-primjer PP Vransko jezero, Doktorski rad, PMF, Sveucilište u Zagrebu.

- URL1: http://zadarski.slobodnadalmacija.hr/vijesti/clanak/ id/19399/objavljeni-podaci-za-hrvatsku-zadarska-zupanija-cetvrta-po-broju-pozara--gorjelo-je-821-put, 14.11.2016.

- URL2: http://www.innovativegis.com/basis/mapanalysis/ topic15/topic15.htm, 20.11.2016.

- URL3: Environmental Systems Research Institute, Inc. http:// webhelp.esri.com/arcgisdesktop/9.2/index.

cfm?TopicName=Performing_a_viewshed_analysis, 20.11.2016

- URL4: Environmental Systems Research Institute,Inc., http:// pro.arcgis.com/en/pro-app/tool-reference/spatial-analyst/howfilter-works.htm, 22.11.2016

- URL5 http://desktop.arcgis.com/en/arcmap/10.3/tools/spatialanalyst-toolbox/how-filter-works.htm 12.1.2017.

- Vollmer, F., 2012: Increasing the visibility and effectiveness of development cooperation: how to reconcile two competing objectives? German Development Institute, Bonn.

- Wheatley, D., Gillings, M., 2000: Vision, perception and GIS: developing enriched approaches to the study of archaeological visibility, NATO ASI SERIES A LIFE SCIENCES, 321, 1-27.

- Wechsler, S. P., 1999: Digital Elevation Model (DEM) uncertainty: evaluation and effect on topographic parameters, In ESRI User Conference.

- Worboys, M. F., 1994: Innovations in GIS, CRC Press, pp. 267.

- Procjena ugroženosti Republike Hrvatske od prirodnih i tehničko-tehnoloških katastrofa i velikih nesreća, DUZS, Zagreb, 2009.

\section{SUMMARY}

Selection of observation sites for fire protection system usually includes a performance of viewshed analysis. Application of GIS analytical capabilities, information and communications technology (ICT) and spatiallyoriented data provides the basis of the fire protection system.

In this research, six proposed locations for set up of surveillance cameras within the Zadar County were evaluated according to indicators of visible land cover and the proportion of the visible area relative to the total land area of the Zadar County. The evaluation was performed by analyzing the overlap of the binary viewshed model, type of land cover and layer settlements. Analysis of suitability for proposed location was performed within the project „HOLISTIC“ IPA program of Adriatic Cross-Border Cooperation 2007-2013.

Results indicate that two of the six proposed locations are not suitable for set up of surveillance cameras. On the example of two transmitters, the impact of DEM error on the output results (viewshed model) was analyzed. For the first time on the specific example in Croatia, difference between probable algorithm and standard binary method of determining visibility has been quantified (fig 6 and 7). It can be concluded that the reliability of the viewshed model, or the difference between tested algorithms, depends on geomorphometric features of the terrain on which the analysis takes place.

KEY WORDS: viewshed analysis, probable and binary viewshed, digital elevation model. 